\title{
Ron Eyerman, The Assassination of Theo van Gogh: from Social Drama to Cultural Trauma
}

\author{
Duke University Press, 2008, 232 pages, \\ ISBN-13: 978-0822344063
}

\author{
Hans Vermeulen
}

Published online: 18 April 2010

(C) The Author(s) 2010. This article is published with open access at Springerlink.com

Though Ron Eyerman considers the assassination of Van Gogh to be a central and emblematic event in the recent and the turbulent political developments in the Netherlands he does not restrict his analysis to this event. He throws his nets much wider. The Assassination of Theo van Gogh is a detailed study of an important period in recent Dutch history. Besides van Gogh and Mohammed Bouyeri, his murderer, other protagonists in these developments such as Pim Fortuyn and Hirsi Ali get almost equal attention. Theo van Gogh was cruelly murdered on November 2 in 2004 by a second-generation Moroccan immigrant who had become a devout and radical Muslim. Van Gogh was a controversial public figure who used a rather vulgar language to provoke Christians, Jews and Muslims alike. The last group he sometimes referred to as 'goatfuckers'.

In the first chapter of his book, Eyerman presents his approach. He promises a multidimensional analysis, 'offering not only a thick description, but also a thick explanation' (p. 23). He utilizes three perspectives: a performative approach focusing on the prediscursive performance of action, discourse theory used especially in the analysis of how events like the murder of Theo van Gogh are represented in the media and theories of social drama and cultural trauma. These theories are used to assess the long-term effects of a series of dramatic events, such as the assassinations of Pim Fortuyn and Theo van Gogh, and the screening of the controversial film Submission by van Gogh and Hirsi Ali. The author develops his arguments in the following order. First, he describes and analyzes the murder, its direct context and representation in the media. Then he turns to the 'perpetrators and victims', their life histories, the historical setting, and what they have come to symbolise. In the next chapters, the murder of van Gogh and some other dramatic events are put in a broader historical and global context, relating them to the debate

Hans Vermeulen is an Emeritus Professor.

H. Vermeulen $(\bowtie)$

Institute for Migration and Ethnic Studies, University of Amsterdam, Amsterdam, The Netherlands e-mail: C.J.J.Vermeulen@uva.nl

e-mail: vermeulen@uth.gr 
on the clash of civilisations, the success or failure of Muslim immigrants' integration, changing notions of Dutchness and the dilemma of free speech versus religious freedom.

Eyerman's multidimensional analysis deals with many issues and contains several lines of argument. So there is not one simple or single conclusion, but there are some central arguments. One of the central arguments is about cultural trauma, dealt with in the last chapter. According to Eyerman, 'the murder of Theo van Gogh opened festering sores in Dutch society, including some that were deeply hidden' (p. 162). These festering sores relate to the Second World War and its direct aftermath. The Dutch had not been very active during the war in resisting German occupation. Eyerman speaks about 'the myth of resistance'. They had also hardly protested against the abduction of the Jewish population. These issues were hardly discussed directly after the war when a heroic self-image was needed to rebuild the nation. To this trauma was added the loss of the colonies after the war, the atrocities committed by Dutch soldiers in Indonesia and the arrival of refugees from that country. These traumatic events, as well as later ones including the murder of Theo van Gogh, contributed to shaping Dutch identity.

Though one may have some doubts about certain interpretations of the events and their effects, as I do, Eyerman certainly provides much food for thought and makes an important contribution to the growing literature on the changing political climate in The Netherlands since 2000, a political climate that continues to foster Dutch nationalism and an anti-Muslim public opinion. Even though Eyerman's book has several strengths, I find the jargon of interpretive sociology sometimes more a hindrance than a help in understanding the author's arguments.

Open Access This article is distributed under the terms of the Creative Commons Attribution Noncommercial License which permits any noncommercial use, distribution, and reproduction in any medium, provided the original author(s) and source are credited. 